\title{
Characterizations of thermoplastic protein films from down feather fiber
}

\begin{abstract}
Down feather fiber was modified by formamide which acts as a plasticizer and then hot-pressed into thermoplastic down films. After hot-pressed, the mechanical properties of thermoplastic down films had a close relationship with the exposure time periods. The maximum tensile strength of thermoplastic down films can reach 28.7MPa after exposure to atmosphere for 40 days. ATR-FTIR curves proved that there were hydrogen bonds forming between amino and amide groups of down feather fiber and formamide. WXRD patterns showed that the crystalline region of down feather fiber was destroyed by formamide during hot-pressing and then reformed after exposure to atmosphere for several days. TGA curves showed that thermoplastic down films has lower moisture compared with down feather fiber suggesting that high temperature removed the most of hydrogen-bound water in down feather fiber and then there are chemical reaction between down feather fiber and formamide.
\end{abstract}

Keywords: down feather fiber, formamide, characterization, thermoplastic films
Volume I Issue I - 2017

\author{
Ke Zhang, Kai Yang, Pei Lv, Wenbin Li
}

Wuhan Textile University, China

Correspondence: Wenbin Li,Affiliation, College of Textiles, Wuhan Textile University, Wuhan, Hubei Province, China, Tel +8 60275936 774I, Fax +860275936 774I,

Email wenbinli_wtu@163.com

Received: November 15, 2016 | Published: January 17, 2017

\section{Introduction}

Concern for the environment and shortage of oil is driving research into ways to reuse natural protein fibers, which are usually biodegradable, renewable and environmentally friendly compared with synthetic polymers. One important method of reusing protein fibers is to extract keratin from these protein fibers using complex chemical methods, the keratin was then blended with synthetic polymer to produce protein biomaterials. Unfortunately, keratin solution is unstable in the process of extruding and hot-pressing under high temperature due to the destruction of its super-molecular structure. Consequently, various natural protein fibers such as feather fiber, wool fiber and silk fiber have been straightly applied as filler to produce composites. ${ }^{1-8}$ Feather fibers have been thermally preceded into protein films by using convenient plasticizing agents, such as glycerol and soybean oil..$^{-11}$ However, the film modified by glycerol showed higher weight loss of glycerol, which limited its application. Furthermore, down feather dimensions (highly order, hierarchical branched structures) make it unsuitable for producing thermoplastic protein films. In this context, down feather was cut into small pieces of fiber and then ground into down feather fiber (SDP), which has the size distribution between $0.2-12 \mu \mathrm{m}$ and the average particle size of $2.34 \mu \mathrm{m} .{ }^{12}$ Based on our previous study, down feather fiber has nearly 14 times the specific surface area of down feather and was blended with polypropylene and polyurethane respectively. ${ }^{13-18}$ Therefore, more hydrogen bonds can form between down feather fiber and plasticizing agent resulting into higher mechanical properties of thermoplastic down films after hot-processing.

Formamide is one of the most important biochemical models and has two $\mathrm{C}=\mathrm{O}$ and one $\mathrm{N}-\mathrm{H}$ corresponding to the receptor and donor of hydrogen bond proton respectively. So there are many $\mathrm{N}-\mathrm{H} \cdots \cdots \mathrm{O}=\mathrm{C}$ bonds in the backbone of formamide and can react with $-\mathrm{NH}_{2}$ and -NH by forming various hydrogen bonds. Down feather fiber, which has a large amount of the amino acid, of which the cysteine is a sulfurcontaining amino acid and can form sulfur-sulfur (S-S) cystine bonds with other intra- or intermolecular cysteine molecules. Therefore, this indicates that the formamide is an excellent plasticizing agent to prepare thermoplastic down feather fiber films. In this paper, down feather fiber obtained from down feather after physical grounding was blended with various amounts of formamide and then hot-pressed into thermoplastic down films. The influences of exposure time periods on the mechanical properties of thermoplastic down films were investigated. The weight loss of formamide as a function of exposure to atmosphere was also investigated. In addition, chemical reaction, microstructure changes and thermal properties of thermoplastic films were also characterized.

\section{Materials and methods}

\section{Materials}

Down feather fiber was produced from duck feather on a purposebuilt machine. ${ }^{12}$ Formamide (A.R.) was supplied from Kedi Co. Ltd., Tianjin, China.

\section{Fabrication of thermoplastic down film}

Thermoplastic down films with different contents of formamide were prepared according to the following procedures: down feather fiber was added into a beaker and then formamide was slowly added into the beaker. To avoid some aggregates of down feather fiber, the blend was mixed in an All-Purpose High-speed Smashing Machines. Then, the blend was sandwiched between two Tefloncoated compression molder and hot-pressed into thin films on a plate vulcanization machine (XLB-D350 $\times 350$, china). After pressing, the film was removed from the molder and cooled until its temperature reached room temperature. This resulted in circular films with around $1.5 \mathrm{~mm}$ in thickness and different diameter. The amount of formamide used in experiments was $20 \%, 25 \%, 30 \%, 35 \%, 40 \%, 45 \%$ and $50 \%$ to the weight of down feather fiber.

\section{Measurements and characterizations}

Optical morphology of thermoplastic down films was taken by Canon D100. Mechanical properties were tested on an Instron 5566 Universal Testing Machine, at a gauge length of $50 \mathrm{~mm}$ and strain 
rate of $50 \mathrm{~mm} / \mathrm{min}$. The length and width of samples respective was $60 \mathrm{~mm}$ and $20 \mathrm{~mm}$. Each sample was tested 5 times and the results were averaged. The weight of the film was tested immediately after the film was cooled down, after that, the samples were weighted every three days at room temperature. Weight loss was calculated according to the equation (1):

$$
\text { Weight } \operatorname{loss}(\%)=\left(W_{1}-W_{2}\right) / W_{1}
$$

Where, $\mathrm{W}_{1}$ is the original weight of the film; $\mathrm{W}_{2}$ is the weight of film after different storage time.

The ATR-FTIR measurements of thermoplastic films were carried out on a BRUKER TENSOR 27 spectrometer with an ATR cell. Each spectrum was an average of 32 scans recorded at a resolution of $4 \mathrm{~cm}-1$ in the range of $4000-600 \mathrm{~cm}^{-1}$. WXRD measurements were performed on a D/MAX-III instrument by use of $\mathrm{Cu}$-ka radiation (wave-length $=0.154 \mathrm{~nm}$ ) to investigate the structure of samples. Generator intensity was $35 \mathrm{Kv}$; generator current was $30 \mathrm{~mA}$. The $\mathrm{PP} / \mathrm{DFF}$ composites were scanned within the range of $2 \theta=5-50^{\circ}$ in step of $0.02^{\circ}$. Thermal analysis was performed using a TG $209 \mathrm{~F} 1$ (NETZSCH) from $25^{\circ} \mathrm{C}$ to $600^{\circ} \mathrm{C}$ at a heating rate of $20^{\circ} \mathrm{C} / \mathrm{min}$, in flowing nitrogen atmosphere $(10 \mathrm{ml} / \mathrm{min})$.

\section{Results and discussion}

\section{Effect of formamide content}

Down feather fiber/formamide blends with different formamide contents were hot-pressed at $5 \mathrm{Mpa}$ and $150^{\circ} \mathrm{C}$ for $5 \mathrm{~min}$. The tensile strength and elongation at break of thermoplastic down films with different formamide contents are shown in Figure 1. It was apparent that with the increase in formamide content, the tensile strength of thermoplastic down films decreased steadily, but the elongation at break reached a maximum value when formamide content was around $35 \%$. It is obvious that the thermoplastic down films became more ductile with the increase in formamide content. When the formamide content was lower than $20 \%$ the pressed films were too brittle to obtain good mechanical properties and films with greater than $50 \%$ formamide were incomplete after hot-pressing. It is evidently that adding of formamide made the thermoplastic down film ductile and deformable. Furthermore, thermoplastic down films became tough when they were exposed to atmosphere for different days, as seen from Table 1. For thermoplastic down films after exposure to atmosphere for different days, the tensile strength and Young's modulus increased greatly while the elongation at break decreased evidently. After a long time exposure to atmosphere, most formamide was removed from the microstructure of thermoplastic down films and then the films became more compact and adjust formamide molecular and down feather fiber to adopt new structure, which has fewer holes and more chemical bonds between down feather fiber and formamide.

\section{Loss of formamide of thermoplastic down films}

The weight loss percentages of the thermoplastic down films (pressed at $130^{\circ} \mathrm{C}$ and $5 \mathrm{Mpa}$ for $5 \mathrm{~min}$ ) under different storage time are shown in Figure 2. The histogram of thermoplastic down films showed a sharp weight loss within 9days meaning the removal of formamide from the films. After 12days the weight loss of films became stable comparatively suggesting that formamide is a good plaster compared with glycerol. It could be seen clearly that after 1day and 2days no evident formamide was found on the surface of thermoplastic down films even if the films were exposed to atmosphere for 15days.

Table I Mechanical properties of thermoplastic down films after different exposure time periods

\begin{tabular}{llll}
\hline Storage time [day] & \multicolumn{2}{l}{ Mechanical properties } \\
\cline { 2 - 4 } & Elongation at break [mm] & Young's modulus [N/mm] & Tensile strength [MPa] \\
\hline 0 & $12.83 \pm 0.97$ & $3.898 \pm 0.21$ & $1.99 \pm 0.10$ \\
9 & $10.52 \pm 0.81$ & $26.49 \pm 1.54$ & $6.74 \pm 0.39$ \\
18 & $6.16 \pm 0.43$ & $68.49 \pm 3.77$ & $15.39 \pm 1.03$ \\
30 & $3.25 \pm 0.19$ & $113.46 \pm 8.49$ & $22.72 \pm 1.67$ \\
36 & $2.01 \pm 0.12$ & $179.64 \pm 6.13$ & $26.91 \pm 1.53$ \\
$>40$ & $1.867 \pm 0.11$ & $198.36 \pm 7.09$ & $28.74 \pm 1.03$
\end{tabular}

\section{ATR-FTIR spectra of thermoplastic films from down} feather fiber

The ATR-FTIR spectral data of down feather fiber, formamide and thermoplastic down films are presented in Figure 3. The spectral of formamide shows characteristic peaks at $3318 \mathrm{~cm}^{-1}, 3185 \mathrm{~cm}^{-1}$, $1668 \mathrm{~cm}^{-1}$, which are associated with $\mathrm{NH}_{2}$-antisymmetrical stretching vibration, $\mathrm{NH}_{2}$-symmetrical stretching vibration and stretching vibration of $\mathrm{C}=\mathrm{O}$, respectively. The spectral data of down feather fiber shows typical peaks at $2930 \mathrm{~cm}^{-1}$ and $1645 \mathrm{~cm}^{-1}$, which are corresponded to $\mathrm{CH}_{2}$-antisymmetrical stretching vibration and stretching vibration of $\mathrm{C}=\mathrm{O}$, respectively. Theoretically, formamide can be expected to react with down feather fiber to form amounts of hydrogen bonds, which can put the down feather fiber together. However, the new hydrogen bonds could not be observed in spectra since large number of hydrogen bonds already exists in the formamide solution and backbone of down feather fiber. This phenomenon indicates that formamide is an excellent plasticizing agent, which not only can improve mechanical properties of films but also sustain the excellent properties of down feather fiber.

\section{WXRD curves of thermoplastic down films}

The WXRD curves of down feather fiber, thermoplasticdown films with $50 \%$ formamide and thermo plastic down films with $50 \%$ formamide after 20days were shown in Figure 4. Down feather fiber showed typical diffraction pattern of $\alpha$-keratins with a prominent 2 theta peak at $22^{\circ}$, which corresponded to the crystalline spacing of $4.39 \AA .{ }^{19}$ It could not be found that the typical diffraction pattern of thermoplastic down films due to the destruction of crystalline region of down feather fiber. Furthermore, the intra molecular and intermolecular bonding of down feather fiber was replaced by formamide during the process of hot-pressing. After 20days, thermoplastic down films exhibited the diffraction pattern, which shifted higher 2 theta compared with that of down feather fiber. After 20 days exposure to 
atmosphere, some formamide was removed from the microstructure of thermoplastic down films and the macromolecules of down feather had enough time to align them and reform $\alpha$-keratins.

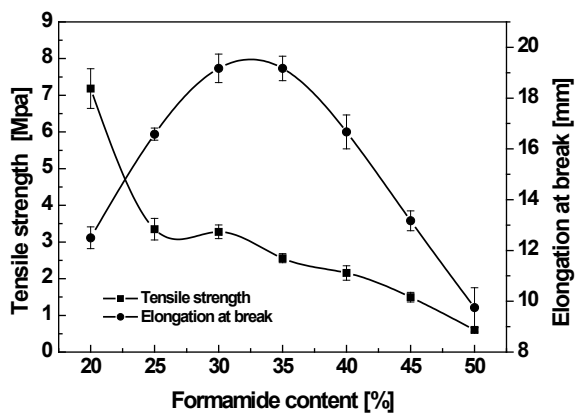

Figure I Tensile strength and elongation at break of thermoplastic down films with different formamide content.

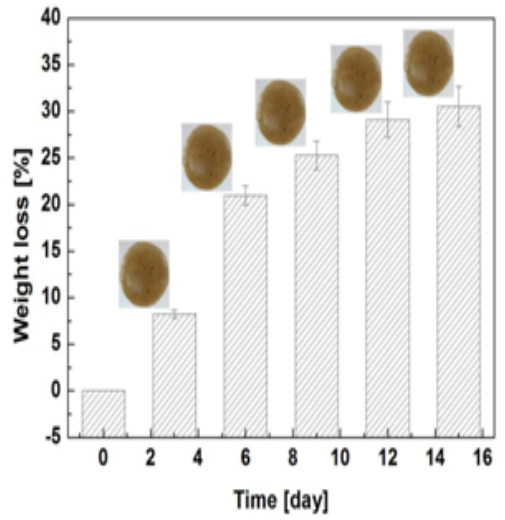

Figure 2The weight loss of thermoplastic down films exposed to atmosphere with different time periods.

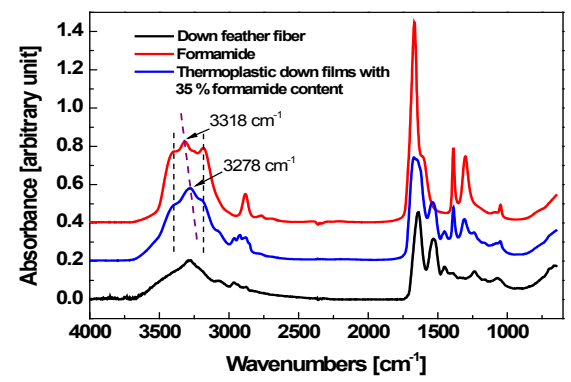

Figure 3 ATR-FTIR spectra of down feather fiber, formamide and thermoplastic down films.

\section{Thermo gravimetric analysis of thermoplastic down films}

The TG curves of down feather fiber and thermoplastic down films with different formamide content are shown in Figure 5. Two evident weight loss stages were observed in the TG curve of down feather fiber. The first one in temperature range of $20-130^{\circ} \mathrm{C}$ is generally corresponded to the evaporation of moisture and the second one around $210-450^{\circ} \mathrm{C}$ is ascribed to the thermal degradation of down feather fiber. All the thermoplastic down films show two evident weight loss steps, which are corresponded to the thermal degradation of formamide and down feather fiber, respectively. The weight loss of formamide in thermoplastic down films increases with the increase in formamide amount. In addition, the residue of thermoplastic down films at $600^{\circ} \mathrm{C}$ decreases with the increase of the formamide. For thermoplastic down film with $20 \%$ formamide, the weight loss is lower than that of down feather fiber in temperature range of 30$170^{\circ} \mathrm{C}$ and then is higher around $170-600^{\circ} \mathrm{C}$. This indicates that the moisture of thermoplastic down films decreased after down feather fiber/formamide was hot-pressed. Moreover, the temperature corresponding to thermal degradation of down feather fiber was found almost unaffected whether down feather fiber was plasticized by formamide.

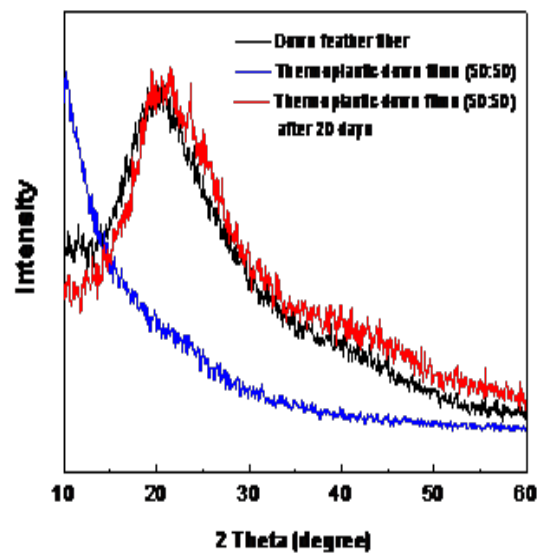

Figure 4WXRD curves of down feather fiber, thermoplastic down films with $50 \%$ formamide, and thermoplasticdown films with $50 \%$ formamide after 20 days.

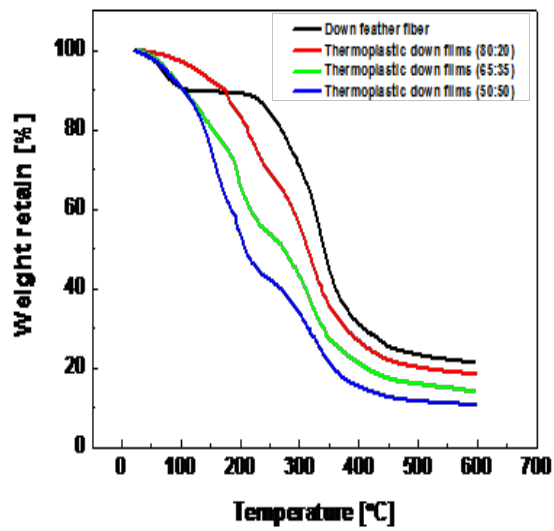

Figure 5 TG curves of down feather fiber and thermoplastic down films.

\section{Conclusion}

The results of this study indicate that the formamide is a good plasticizer, which not only improves the mechanical properties of thermoplastic down films largely, but also sustains the excellent protein properties of down feather fiber. With the increase in formamide content, the tensile strength and Young's modulus decreased steadily. However, the elongation at break reached a maximum value when formamide content was around $35 \%$. This suggests the more formamide content, the more ductile thermoplastic down films we can obtained. It worth noting that the mechanical properties of thermoplastic down films have a close relation with the exposure time periods after hot- 
pressing. ATR-FTIR spectra showed that there was no new absorbent peaks appeared in thermoplastic down films indicating that down feather fiber hot-pressed with formamide sustain the macromolecular structure of down feather fiber and there are possible hydrogen bonds between down feather fiber and formamide. However, the hydrogen bonds between down feather fiber and formamide cannot be detected by FTIR due to the present in the formamide solution and backbone of down feather fiber. WXRD curves indicated that the $\alpha$-keratins of down feather fiber was weakened immediately after hot-pressing and then reformed after exposed to atmosphere for 20 days. TGA curves showed that thermoplastic down films has lower moisture compared with down feather fiber suggesting that high temperature removed the most of hydrogen-bound water in down feather fiber and then there are chemical reaction between down feather fiber and formamide. Moreover, the temperature corresponding to thermal degradation of down feather fiber was found almost independent of whether down feather fiber was plasticized by formamide.

\section{Acknowledgments}

We greatly acknowledge the support from the National Natural Science Foundation of China (Project No. 51203124, 51325306).

\section{Conflict of interest}

Author declares there is no conflict of interest in publishing the article.

\section{References}

1. Barone JR. Polyethylene/keratin fiber composites with varying polyethylene crystallinity. Composites Part A: Applied Science and Manufacturing. 2005;36(11):1518-1524.

2. Barone JR, Schmidt WF, Liebner CFE. Compounding and molding of polyethylene composites reinforced with keratin feather fiber. Composites Science and Technology. 2005;65(3-4):683-692.

3. Barone JR, Schmidt WF. Polyethylene reinforced with keratin fibers obtained from chicken feathers. Composites Science and Technology. 2005;65(2):173-181.

4. Bullions TA, Hoffman D, Gillespie RA, et al. Contributions of feather fibers and various cellulose fibers to the mechanical properties of polypropylene matrix composites. Composites Science and Technology. 2006;66(1):102-114.

5.Hernández ALM, Santos CV, De-Icaza M, et al. Dynamical-mechanical and thermal analysis of polymeric composites reinforced with keratin biofibers from chicken feathers. Composites Part B: Engineering. 2007;38(3):405-410.
6. Cheng S, Lau KT, Liu T, et al. Mechanical and thermal properties of chicken feather fiber/PLA green composites. Composites Part B: Engineering. 2009;40(7):650-654.

7. Conzatti L, Giunco F, Stagnaro P, et al. Polyester-based biocomposites containing wool fibres. Composites Part A: Applied Science and Manufacturing. 2012;43(7):1113-1119.

8. Li W, Qiao X, Sun K, et al. Mechanical and viscoelastic properties of novel silk fibroin fiber/poly( $\varepsilon$-caprolactone) biocomposites. J Appl Polym Sci. 2008;110(1):134-139.

9. Barone JR, Schmidt WF, Liebner CFE. Thermally processed keratin films. J Appl Polym Sci. 2005;97(4):1644-1651.

10. Barone JR, Schmidt WF, Gregoire NT. Extrusion of feather keratin. $J$ Appl Polym Sci. 2006;100(2):1432-1442.

11. Hong CK, Wool RP. Development of a bio-based composite material from soybean oil and keratin fibers. J Appl Polym Sci. 2005;95(6):1524-1538.

12. Xu W, Wang X, Cui W, et al. Characterization of superfine down powder. J Appl Polym Sci. 2009;111(5):2204-2209.

13. Liu X, Gu S, Xu W. Thermal and Structural Characterization of Superfine Down Powder. J Therm Anal Calorim. 2013;111(1):259-266.

14. Guo L, Chen F, Zhou Y, et al. The Influence of Interface and Thermal Conductivity of Filler on the Nonisothermal Crystallization Kinetics of Polypropylene/Natural Protein Fiber Composites. Composites Part B. Engineering. 2015;68:300-309.

15. Chen F, Xiong L, Cai M, et al. Adsorption of Direct Fast Scarlet 4BS Dye from Aqueous Solution onto Natural Superfine Down Particle. Fibers Polym. 2015;16(1):73-78.

16. Liu X, Xu W, Li W, et al. Mechanical and Water Vapor Transport Properties of Polyurethane/Superfine Down Powder Composites Membranes. Polym Eng Sci. 2010;50(12):2400-2407.

17. Liu X, Xu W, Peng X. Effects of Stearic Acid on the Interface and Performance of Polypropylene/Superfine Down Powder Composites. Polym Compos. 2009;30(12):1854-1863.

18. Liu X, Huang J, Wenbin Li, et al. Coating Superfine Down Powder on Polypropylene for the Production of Dyeable Fibers. Fibers Polym. 2011;12(2):220-225.

19. Xu W, Guo W, Li W. Thermal Analysis UltrafineWool Powder. J Appl Polym Sci. 2003;87(14):2372-2376. 